\title{
INSTRUKCJA KANCELARYJNA KUL A INSTRUKCJE UNIWERSYTETU MARII CURIE-SKLODOWSKIEJ I UNIWERSYTETU ŚLĄSKIEGO W KATOWICACH. PORÓWNANIE NORMATYWÓW KANCELARYJNYCH
}

Nie od dziś wiadomo, że system kancelaryjny stosowany w instytucji decyduje nie tylko o formach i sposobach tworzenia dokumentacji, lecz wpływa również na sprawne działanie jednostki organizacyjnej. Kancelaria działa dobrze, jeśli jest jasny oraz przejrzysty podział kompetencji i czynności między poszczególnymi komórkami organizacyjnymi i pracownikami. Dokumentacja powstająca w danej jednostce jest tworzona i przechowywana według rodzajów spraw. W obowiązującym dawniej systemie dziennikowym wpisy w dzienniku korespondencyjnym decydowały o miejscu danej sprawy w całości dokumentacji powstającej w instytucji. Współcześnie stosuje się najczęściej bezdziennikowy system kancelaryjny wprowadzany w polskich kancelariach od lat 30. ubiegłego wieku. System ten oparty jest o instrukcję kancelaryjną i wykaz akt. Początkowo punktem wyjścia do tworzenia wykazów akt była struktura instytucji. W ramach jej wydziałów, oddziałów czy referatów określano rzeczowe rodzaje spraw. Stopniowo jednak odchodzono od tego strukturalno-rzeczowego układu na rzecz typowo rzeczowego wykazu akt. Nowoczesny wykaz to niezależna od struktury instytucji rzeczowa klasyfikacja akt obejmująca całość dokumentacji powstającej w toku działalności danej jednostki organizacyjnej. Budowa współczesnego wykazu akt oparta jest o cztery elementy, a mianowicie symbole klasyfikacyjne w systemie dziesiętnym, hasło klasyfikacyjne, oznaczenie kategorii archiwalnej oraz opcjonalne uszczegółowienie hasła klasyfikacyjnego. Sa to tzw. jednolite rzeczowe wykazy akt.

Jak już zaznaczono, koniecznym elementem współczesnego systemu kancelaryjnego jest instrukcja kancelaryjna. Jest to normatyw, w którym powinny zostać omówione takie kwestie, jak:

- $\quad$ organizacja biurowości (np. lista czynności biurowych, podział między urzędników, kto odpowiada za kontrolę czynności)

* Tomasz Nowicki - dr hab. historii, adiunkt w Katedrze Historii Ustroju i Administracji Polski KUL, członek Rady Archiwalnej KUL, e-mail: tonowi@kul.pl 
- system kancelaryjny (szersza informacja o sposobie rejestrowania spraw, zakresie rejestrowania, łączenia w akta sprawy i w jednostki kancelaryjne oraz sposób układania jednostek kancelaryjnych)

- obieg dokumentacji (omówienie urzędowej drogi pisma - sprawy i miejsc jego zatrzymania - sekretariatu, komórek organizacyjnych, referentów itd.)

- dekretacja, sposób załatwiania spraw, formułowania odpowiedzi, podpisywania pism i wysyłania korespondencji.

Ponadto w instrukcji kancelaryjnej powinny zostać określone zasady przechowywania dokumentacji w komórce organizacyjnej oraz sposób i terminy przekazywania jej do archiwum zakładowego. Mogą być także zawarte regulacje dotyczące postępowania w przypadku likwidacji bądź reorganizacji jednostki lub komórki organizacyjnej, postępowania ze szczególnymi rodzajami dokumentacji (np. zbiory zastrzeżone, dokumentacja poufna, tajna itp.) czy też wykorzystywania programów komputerowych i informatyki w pracy kancelaryjnej. Z kolei $\mathrm{w}$ instytucjach wykorzystujących elektroniczny system zarządzania dokumentacją (EZD) instrukcja powinna dokładnie omawiać czynności kancelaryjne wykonywane w ramach systemu i ich dokumentowanie, zwłaszcza zaś kwestie dotyczące prowadzenia rejestru przesyłek wpływających i wychodzących oraz spisów spraw, wykonywanie dekretacji, podpisywanie dokumentów podpisem elektronicznym oraz gromadzenia dokumentów elektronicznych tworzących akta spraw.

W Katolickim Uniwersytecie Lubelskim Jana Pawła II wspomniany normatyw kancelaryjny obowiązuje od $2002 \mathrm{r}^{1}{ }^{1}$ Wprowadzenie wówczas bezdziennikowego systemu kancelaryjnego, było ważnym krokiem sprzyjającym do uporządkowania i ujednolicenia dokumentacji powstającej w komórkach organizacyjnych Uczelni. Był to $\mathrm{w}$ tym czasie niewątpliwie znaczący postęp ${ }^{2}$. Powstaje jednak pytanie, czy po kilkunastu latach instrukcja kancelaryjna KUL spełnia swoją rolę? W niniejszym artykule przyjrzymy się zatem temu normatywowi i porównamy go do podobnych aktów obowiązujących na dwóch innych polskich uczelniach, a mianowicie z wprowadzoną w 2008 r. Instrukcją kancelaryjną UMCS w Lublinie $^{3}$ oraz wprowadzoną od 2012 r. Instrukcją kancelaryjną Uniwersytetu Śląskiego w Katowicach ${ }^{4}$.

$\mathrm{Na}$ początku zestawmy te normatywy na poziomie tytułów rozdziałów. By ułatwić porównanie, tytuły omawianych regulacji przedstawimy w formie tabelarycznej.

${ }^{1}$ Instrukcja kancelaryjna oraz jednolity rzeczowy wykaz akt są załącznikami do Zarzadzenia Rektora KUL w sprawie wprowadzenia bezdziennikowego systemu kancelaryjnego z 21 grudnia $2001 \mathrm{r}$.

${ }^{2}$ Zob. M. Pawelec, Zarządzanie dokumentacja w świetle instrukcji kancelaryjnej wprowadzonej w Katolickim Uniwersytecie Lubelskim, „Archiwista Polski” (dalej: AP), 28 (2002) nr 4, s. 3942; tenże, Funkcjonowanie jednolitego wykazu akt w Katolickim Uniwersytecie Lubelskim, AP, 35 (2004) nr 3, s. 57-64; tenże, Dokumenty ujarzmione, „Przegląd Uniwersytecki”, 14 (2002) nr 2 (76), s. 14-15.

${ }^{3}$ Instrukcję kancelaryjną UMCS wprowadziło Zarządzenie Nr 1/2008 Rektora UMSC z 10 stycznia $2008 \mathrm{r}$.

${ }^{4}$ Instrukcję kancelaryjną Uniwersytetu Śląskiego w Katowicach wprowadzono zarządzeniem Rektora UŚ nr 107 z 14 grudnia 20011 r. 


\begin{tabular}{|c|c|c|}
\hline UL & UMCS & Ś \\
\hline $\begin{array}{l}\text { 1. Postanowienia wstępne } \\
\text { 2. Obieg akt } \\
\text { 3. Odbiór korespondencji } \\
\text { przy-chodzącej (wpływów) } \\
\text { 4. Przeglądanie i } \\
\text { przydzielanie wpływów } \\
\text { 5. Rejestrowanie i } \\
\text { znakowanie spraw } \\
\text { 6. Załatwianie spraw } \\
\text { 7. Aprobata } \\
\text { 8. Sporządzanie czystopisów } \\
\text { 9. Podpisywanie pism } \\
\text { 10. Wysyłanie pism } \\
\text { 11. Przechowywanie akt } \\
\text { 12. Ocena archiwalna akt } \\
\text { 13. Przekazywanie } \\
\text { akt do Archiwum } \\
\text { Uniwersyteckiego } \\
\text { 14. Udostępnianie akt } \mathrm{w} \\
\text { Archiwum jednostkom } \\
\text { organizacyjnym } \\
\text { Uniwersytetu }\end{array}$ & 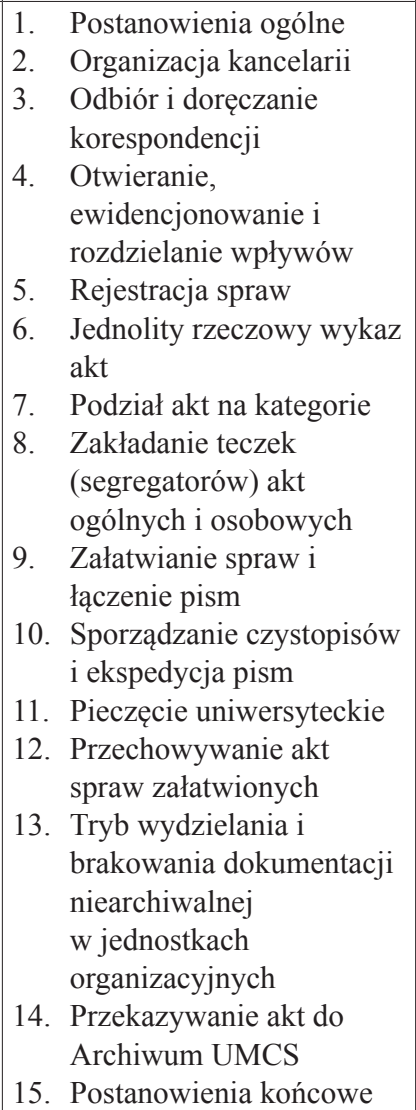 & 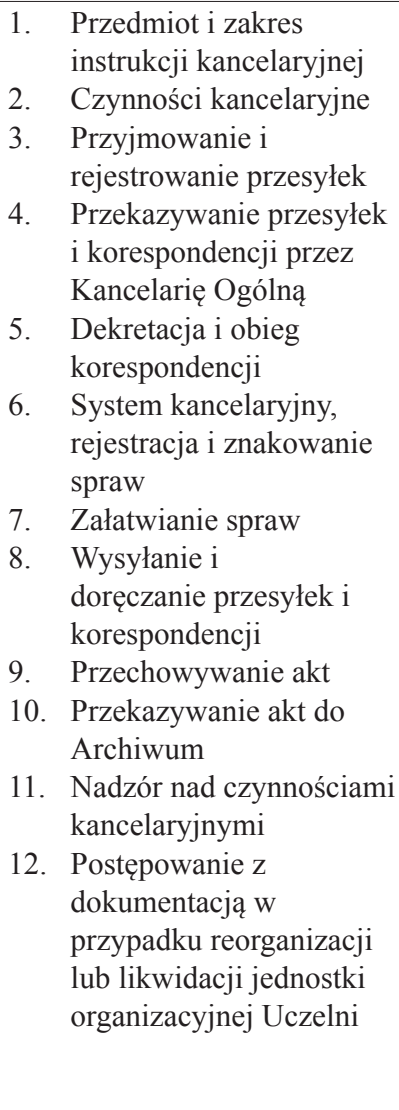 \\
\hline
\end{tabular}

Patrząc na tytuły rozdziałów można przypuszczać, że generalnie wszystkie prezentowanie instrukcje zawierają podobne treści. Widać, że w porównywanych instrukcjach kancelaryjnych trzech polskich uniwersytetów omówione są kwestie związane z:

a) obiegiem akt (KUL), organizacją kancelarii (UMCS) czy też czynnościami kancelaryjnymi (UŚ);

b) postępowaniem z korespondencją przychodzącą i przekazywaniem do komórek organizacyjnych ( KUL: ust. 3 i 4; UMCS: ust. 3 i 4; UŚ: ust. 3, 4 i 5);

c) postępowaniem w komórkach organizacyjnych merytorycznie pracujących nad daną sprawą (KUL: ust. 5, 6, 7, 8, 9 i 10; UMCS: ust. 5, 8, 9 i 10; US: ust. 5, 6, 7 i 8); UŚ: ust. 9);

d) przechowywaniem dokumentacji bieżącej (KUL: ust. 11; UMCS: ust. 12;

e) kwalifikowaniem do odpowiedniej kategorii oraz przekazywaniem do archiwum uniwersyteckiego (KUL: ust. 12 i 13; UMCS: ust. 13 i 14; UŚ: ust. 10).

Dodatkowe elementy w poszczególnych instrukcjach to omówienie kwestii związanych z udostępnianiem akt w archiwum uniwersyteckim (KUL: ust. 14) 
czy też związanych z nadzorem nad czynnościami kancelaryjnymi (UŚ: ust. 11), a także szczegółowe opisanie pieczęci uniwersyteckich (UMCS: ust. 11) oraz przedstawienie sposobów postępowania w przypadku powołania lub likwidacji jednostki organizacyjnej lub stanowiska pracy (UMCS: ust. 15; UŚ: ust. 12).

Zatem jeśli spojrzeć na omawiane normatywy przez pryzmat zagadnień, które omawiają, to oczywiście rozbieżności nie są znaczące. Jednak już nawet pobieżne zapoznanie się z instrukcjami KUL, UMCS i UŚ pokazuje, że istnieją między nimi istotne różnice. Szczególnie od stosowanego wzorca dla tego typu normatywów odbiega instrukcja KUL. Jest ona nie tyle instrukcją kancelaryjną, co raczej instrukcją postępowania z dokumentacją. Bardziej przypomina instrukcję obiegu pism, niż klasyczną instrukcję kancelaryjną, choć oczywiście zawiera elementy charakterystyczne dla tego typu aktów prawnych. Ponadto niektóre jej zapisy są wyjątkowo ogólne.

W instrukcji KUL znajdujemy jedynie w postanowieniach wstępnych ogólnikowe sformułowanie mówiące, że „przedmiotem Instrukcji są typowe czynności kancelaryjne". Brakuje w tym miejscu dokładniejszego wyjaśnienia, o jakie czynności może chodzić i jakie komórki organizacyjne uniwersytetu te typowe czynności kancelaryjne wykonują. W dalszej części normatywu znajdujemy oczywiście zapisy informujące o czynności aktotwórczych, gdyż są opisane w następnych paragrafach mówiących o obiegu akt, o odbiorze korespondencji, o przeglądaniu i przydzielaniu wpływów, o rejestrowaniu i znakowaniu czy załatwianiu spraw.

Porównując powyższe zapisy instrukcji KUL z normatywem śląskim widzimy jednak istotne różnice. W przepisach kancelaryjnych UŚ już $\mathrm{w} \S 1$ zaznaczono, że „czynności kancelaryjne obejmują przyjmowanie i ewidencjonowanie wpływów, ich rozdział oraz sposób załatwiania spraw". Co więcej, dokładniejszemu określeniu czynności kancelaryjnych poświęcono cały rozdział II instrukcji UŚ. Wyjaśniono tutaj nie tylko zbiorczo, co należy zaliczać do czynności kancelaryjnych, lecz szczegółowo wymieniono te czynności, które wykonuje Kancelaria Ogólna uniwersytetu ( $(4)$. Wskazano w tym miejscu przede wszystkim czynności aktotwórcze formalne nie związane z merytorycznym tworzeniem odpowiedzi, ale jest to zrozumiałe w przypadku takiej komórki organizacyjnej jak Kancelaria Ogólna. Natomiast w $\S 5$ instrukcji UŚ wymieniono komórki organizacyjne uniwersytetu, które także wykonują czynności kancelaryjne (np. gabinet rektora, sekretariat kanclerza, dziekanat, referenci spraw itd.). Dopiero w dalszej części tego normatywu zostały dokładniej omówione czynności kancelaryjne tak formalne (przyjmowanie i rejestrowanie przesyłek i korespondencji, przekazywanie do właściwych jednostek uczelni, dekretacja, wysyłanie i doręczanie adresatom), jak też merytoryczne (zakładanie i znakowanie akt spraw, rejestracja spraw, tworzenie odpowiedzi i załatwianie spraw, pieczętowanie i podpisywanie pism). Podobnie instrukcja UMCS w rozdziale o organizacji kancelarii wymienia dokładnie komórki uczelni wykonujące czynności kancelaryjne ( 33 ust.2), zaś $\mathrm{w} \S 5$ podaje siedem podstawowych czynności kancelaryjnych, czego brak w instrukcji KUL.

Kolejną od razu zauważalną różnicą między instrukcją KUL, a instrukcjami UŚ czy UMCS, jest brak wytlumaczenia wielu nieodzownych w praktyce kancelaryjnej pojęć. Nawet jeśli niektóre określenia pojawiają w tekście instrukcji 
KUL, to albo nie są wcale definiowane, albo wyjaśnienie terminów jest nieprecyzyjne, albo nawet czasami nieprawidłowe. Nie oznacza to bynajmniej, że niektóre zastosowane nazwy nie zostały uwzględnione. W Postanowieniach wstępnych (§ 1) instrukcja kancelaryjna KUL omawia, co to jest wykaz akt, akta, registratura i referent sprawy. W porównaniu jednak do listy 23 terminów wyjaśnionych tak w instrukcji UMCS, jak i UŚ, jest to liczba zbyt mała. Można oczywiście w kolejnych częściach instrukcji kancelaryjnej KUL szukać interpretacji niektórych pojęć, jednakże w tego typu dokumentach przyjęte jest, żeby obowiązująca $\mathrm{w}$ terminologia była zebrana $\mathrm{w}$ jednym miejscu na początku normatywu. Właśnie tak, jak ma to miejsce w instrukcjach UMCS i UŚ.

Kolejna kwestia, to wspomniane już wyżej nieprecyzyjne lub nawet błędne wyjaśnianie terminów w instrukcji kancelaryjnej KUL. Korzystającym z tego normatywu na niewiele się przyda informacja, że akta, to „wszelka dokumentacja niezależnie od treści i formy wykonania". Pojęcie to po raz kolejny wyjaśniono w $\S 12$ ust. 1, ale dodano tutaj, że akta „to wszelka dokumentacja powstała w toku działalności Uniwersytetu". Te wyjaśnienia są wprawdzie jak najbardziej poprawne, lecz w kontekście celów, dla jakich wprowadza się instrukcje kancelaryjne, warto by dodać, że chodzi o taką dokumentację, która służy do załatwiania sprawy. Zatem mało przydatne jest zdefiniowanie terminu akta. O wiele bardziej istotne byłoby określenie, co to są akta sprawy.

Podobnie nieprecyzyjnie został zdefiniowany termin registratura, który według instrukcji KUL oznacza „miejsce przechowywania akt spraw zakończonych (w sprawach ostatecznie załatwionych), lecz potrzebnych jeszcze do pracy bieżącej poszczególnych jednostek organizacyjnych" (§ 1 ust. 6). Tymczasem w terminologii archiwalnej nie tyle o miejsce chodzi, co raczej o dokumentację o takim charakterze, czyli właśnie o akta spraw zakończonych, zwane też aktami podręcznymi ${ }^{5}$. W ten sposób zresztą pojęcie to definiuje instrukcja obowiązująca w UMCS. § 2 pkt. 2 wyjaśnia termin akta spraw załatwionych (registratura), który oznacza „akta spraw zakończonych (zamkniętych) pozostających przez pewien czas (2 lata) w jednostce organizacyjnej, a następnie przekazywanych do Archiwum UMCS lub na makulaturę".

Poważne wątpliwości budzi definicja pojęcia materiaty archiwalne umieszczona $\mathrm{w}$ instrukcji KUL. Jest to definicja błędna. W § 12 ust. 1 można wyczytać, że ,akta spraw zakończonych, zwanych dalej materiałami archiwalnymi, pod względem wartości archiwalnej dzielą się na dwie kategorie: 1) posiadające wartość trwałą, wieczystą - kategoria A, 2) posiadające wartość czasową, użytkową - kategoria B". Z kolei w ust. 3 tegoż paragrafu pada kuriozalne stwierdzenie: „materiały archiwalne o czasowej wartości użytkowej”。.

${ }^{5}$ Zob. H. Robótka, Wspótczesna biurowość. Zagadnienia ogólne, Torun 2010, s.80.

${ }^{6}$ Trzeba jeszcze dodać, że ten sam błąd w rozumieniu terminu materiały archiwalne powiela także wprowadzona w 2009 r. Instrukcja archiwalna KUL W § 2 ust. 2 czytamy: „Akta spraw zakończonych, zwanych dalej materiałami archiwalnymi, pod względem wartości archiwalnej dzielą się na trzy kategorie:

a) posiadające wartość trwałą, wieczystą - kategoria „A”,

b) posiadające wartość czasową, użytkową - kategoria „B” 
Trudno zgodzić się z powyższą definicją materiałów archiwalnych ${ }^{7}$. Chcąc być w zgodzie z najnowszą nomenklaturą, nie można uznać za materiały archiwalne dokumentacji czasowo tylko przydatnej do załatwienia sprawy, mającej tylko znaczenie praktyczne i która nie jest przeznaczona na wieczyste (trwałe) przechowywanie. Definicję terminu materiały archiwalne podaje przecież dokładnie artykuł 1 Ustawy z 14 lipca 1983 roku o narodowym zasobie archiwalnym i archiwach (z późniejszymi zmianami). Czytamy w nim, że „Materiałami archiwalnymi wchodzącymi do narodowego zasobu archiwalnego, zwanymi dalej «materiałami archiwalnymi», są wszelkiego rodzaju akta i dokumenty, korespondencja, dokumentacja finansowa, techniczna i statystyczna, mapy i plany, fotografie, filmy i mikrofilmy, nagrania dźwiękowe i wideofonowe, dokumenty elektroniczne w rozumieniu przepisów ustawy z dnia 17 lutego 2005 r. o informatyzacji działalności podmiotów realizujących zadania publiczne (Dz. U. Nr 64, poz. 565, z późn. zm.1) oraz inna dokumentacja, bez względu na sposób jej wytworzenia, mająca znaczenie jako źródło informacji o wartości historycznej o działalności Państwa Polskiego, jego poszczególnych organów i innych państwowych jednostek organizacyjnych oraz o jego stosunkach z innymi państwami, o rozwoju życia społecznego i gospodarczego, o działalności organizacji o charakterze politycznym, społecznym i gospodarczym, zawodowym i wyznaniowym, o organizacji i rozwoju nauki, kultury i sztuki, a także o działalności jednostek samorządu terytorialnego i innych samorządowych jednostek organizacyjnych - powstała w przeszłości i powstająca współcześnie”.

Ta stosunkowo długa definicja wyjaśnia jednak dostatecznie, że za materiały archiwalne można uznać jedynie takie, które mają wartość wieczystą, historyczną. Mówiąc jeszcze inaczej - każda dokumentacja ma znaczenie praktyczne, lecz do archiwalnej zalicza się tylko tę jej część, która po utracie tej wartości praktycznej, ma walor historyczny i dlatego warta jest dalszego przechowywania (archiwalia). Zatem materiały o czasowej przydatności, mające tylko znaczenie praktyczne i podlegające brakowaniu po upływie określonego czasu, nie mogą być nazywane materiałami archiwalnymi. Jest to po prostu dokumentacja niearchiwalna, materiały niearchiwalne czy też niearchiwalia ${ }^{8}$.

Spójrzmy jeszcze, jak pojęcie to traktują dwie pozostałe instrukcje uniwersyteckie? Co ciekawe, zasadniczo termin materiaty archiwalne w obu instrukcjach nie znajduje wyjaśnienia. Jest to o tyle zrozumiałe, że instrukcja kancelaryjna dotyczy działań szeroko rozumianej kancelarii. Na tym etapie całość dokumentacji ma przecież wartość użytkową i praktyczną, niezależnie od tego, czy w przyszłości jakaś część dokumentacji wytworzonej w danej komórce organizacyjnej będzie miała wartość historyczną, a część akt takiej wartości nie uzyska. W in-

c) podlegające dodatkowej ekspertyzie po upływie określonego okresu - kategoria BE”.

${ }^{7}$ Błędna definicja materiałów archiwalnych w normatywach KUL ma zapewne swoją genezę w sformułowaniu znanym z Polskiego słownika archiwalnego (Warszawa 1974, s. 51), gdzie za materiały archiwalne zostały uznane „,wszelkie dokumenty będące wytworem działalności twórców zespołów, kwalifikujące się do trwałego lub czasowego przechowywania w archiwum".

${ }^{8}$ Zob. R. Degen, Dokumentacja i jej podziat, w: Współczesna dokumentacja urzędowa, red. H. Robótka, Toruń 2011, s. 27-28. 
strukcji kancelaryjnej UMCS znajdujemy w $§ 17$ ust. 1 następujące sformułowanie, z punktu widzenia wyjaśnienia omawianego terminu dość enigmatyczne: „Przekazaniu do Archiwum UMCS podlegają materiały archiwalne (oznaczone kategorią A) oraz dokumentacja określona kategorią $\mathrm{B}, \mathrm{z}$ dłuższym niż pięcioletni okres przechowywania". Zapis ten nie wyjaśnia wprawdzie ostatecznie, co jest, a co nie jest materiałem archiwalnym, lecz wyraźnie rozgranicza dokumentację kategorii „A” (o wartości historycznej) od dokumentacji kategorii „B”. Z kolei w instrukcji UŚ nie ma w ogóle mowy o rozróżnieniu powstającej w komórkach uniwersyteckich dokumentacji. Za to problem ten dokładniej omawia instrukcja archiwalna UŚ, do której odwołuje się § 24 ust. 1 instrukcji kancelaryjnej UŚ9 .

Reasumując, bez watpienia termin materiaty archiwalne powinien być wyjaśniony w instrukcji dotyczącej działania archiwum uniwersyteckiego, czyli instrukcji archiwalnej, ponieważ $\mathrm{w}$ archiwum jest już konieczne wyodrębnienie dokumentacji o wartości historycznej (kat. A) od tej, która ma tylko ulotną w czasie wartość praktyczną (kat. B). Nie oznacza to bynajmniej, że wyjaśnienie tego pojęcia nie może znaleźć się w instrukcji kancelaryjnej. Ważne jest jednak, by była to definicja prawidłowa.

Także niektóre rozwiązania instrukcji KUL nie są zgodne z metodą prac kancelaryjnych. Dla przykładu, omawiana instrukcja przewiduje w przypadku spraw niezakończonych $\mathrm{w}$ danym roku ponowną rejestrację $\mathrm{w}$ nowym spisie spraw wraz z nadaniem nowego aktualnego znaku ( $\$ 5$ ust. 10). Nie jest to rozwiązanie słuszne. Co więcej, jest sprzeczne z innym zapisem instrukcji KUL mówiącym, że sprawę rejestruje się tylko raz na podstawie pierwszego pisma ( $\$ 5$ ust. 1). Ostatecznie zatem referent sprawy, który zgodnie z $\S 2$ ust. 2 pkt. 3 daną sprawę rejestruje w spisie spraw, staje przed niemożliwym do rozwiązania problemem. $Z$ jednej strony instrukcja bowiem nakazuje mu ponowną rejestrację niezakończonej w danym roku sprawy i nadanie jej nowego znaku akt. Z kolei inny przepis tej samej instrukcji każe referentowi daną sprawę rejestrować tylko raz.

Jak kwestie te regulują instrukcje UMCS i UŚ? W normatywie UMCS zapisano tylko, że sprawa jest rejestrowana tylko raz, na podstawie pierwszego pisma (§ 8 ust. 4). Nie stosuje się zatem podwójnej rejestracji w spisie spraw. Jeszcze wyraźniej i dokładniej tę kwestię precyzuje instrukcja UŚ: „sprawy niezakończone ostatecznie w ciągu danego roku załatwia się w latach kolejnych bez zmiany dotychczasowego ich znaku i bez wpisywania do nowych spisów spraw" ( $\$ 14$ ust. 6$)^{10}$.

${ }^{9}$ Przepis ten brzmi: „Po upływie okresu przechowywania akt, o którym mowa w par. 23 ust. 6 (tzn. po dwóch latach od zakończenia sprawy licząc od 1 stycznia roku następnego - TN) jednostki organizacyjne przekazują akta spraw zakończonych do Archiwum Uczelni, w trybie i na warunkach określonych przepisami Instrukcji archiwalnej Uniwersytetu Śląskiego".

${ }^{10}$ To samo rozwiązanie przewiduje np. instrukcja wprowadzona rozporządzeniem Prezesa Rady Ministrów z 18 stycznia 2011 r. dla administracji państwowej i samorządowej tak w przypadku stosowania elektronicznego systemu zarządzania dokumentacją ( 28 ust. 1 i 2), jak też przy korzystaniu z tradycyjnych rozwiązań ( $\$ 55$ ust. 1 i 2 ). W obu przypadkach jasno zapisano, że „Sprawę niezakończoną ostatecznie w ciągu roku załatwia się w latach kolejnych bez zmiany dotychczasowego jej znaku. Elementy znaku sprawy pozostają niezmienne” (ust. 1). „Zmiana znaku 
Inne kuriozum zapisane $\mathrm{w}$ instrukcji KUL z 2002 roku, to regulacja dopuszczająca zakładanie teczek na rok akademicki. W § 5 ust. 13 czytamy: „Nowe teczki aktowe i nowe spisy spraw dla każdej teczki aktowej zakłada się w zasadzie na każdy rok kalendarzowy, tzn. 1.01 - 31.12. Sprawy związane z dydaktyką, dotyczące zarówno studentów, doktorantów itp., jak i toku studiów prowadzi się w teczkach zakładanych na rok akademicki, tzn. 1.10 - 30.09”. Ta druga część tej regulacji jest zapisem całkowicie sztucznym. Współczesna kancelaria akt spraw oparta jest o system roku kalendarzowego. Co innego, jeśli mamy do czynienia z aktami osobowymi, jak na przykład akta studenckie, doktoranckie, czy też akta pracowników. Lecz tutaj poniekąd ,punktem wyjścia” jest konkretna osoba, której akta dotyczą. Metodę zakładania teczek akt w systemie roku kalendarzowego potwierdzają porównywane instrukcje UMCS i UŚ. W pierwszej z nich czytamy, że „Teczkę spraw ogólnych zakłada się na jeden rok kalendarzowy. Jeżeli sprawa wymaga wydłużenia tego okresu, wówczas zaznacza się to w opisie teczki, w miejscu przeznaczonym na daty" (§ 11 ust. 3 instrukcji kancelaryjnej UMCS). Z kolei w instrukcji UŚ zapisano: „Spisy spraw i teczki zakłada się na każdy rok kalendarzowy oddzielnie. Dopuszcza się w sytuacji znikomej liczby spraw założonych w ciągu roku dla danej pozycji Jednolitego Rzeczowego Wykazu Akt prowadzenie teczek aktowych ze spisami spraw przez okres dłuższy niż jeden rok. W takim przypadku zakłada się dla każdego roku odrębny spis spraw" (§ 11 ust. 2 instrukcji kancelaryjnej UŚ) ${ }^{11}$.

Instrukcja KUL wyklucza w zasadzie stosowanie pomocniczych rejestrów kancelaryjnych, takich jak np. rejestr przesyłek wpływających i wychodzących, rejestr różnego typu listów (np. poleconych, sądowych, kurierskich), dziennika korespondencyjnego czy książki nadawczej. Dopuszcza się jedynie, by dla spraw, dla których przewidziana jest specjalna forma rejestracji (np. rejestr, kartoteka) nie prowadzić spisów spraw. Nie precyzuje jednak, o jakie sprawy chodzi. Tymczasem samo wprowadzenie systemu bezdziennikowego nie wyklucza stosowania takich pomocy kancelaryjnych. Ale też odwrotnie: pomocnicze stosowanie dziennika korespondencyjnego nie decyduje o zmianie systemu na dziennikowy ${ }^{12}$. Co ciekawe, wyjaśnienie tej relacji znaleźć można w instrukcji UŚ: „W celu kontroli obiegu korespondencji w Uczelni możliwe jest stosowanie dzienników korespondencyjnych wyłącznie jako pomocniczych środków ewidencyjnych. Nie zwalnia to jednak z obowiązku stosowania znaku sprawy i rzeczowego kompletowania akt sprawy w teczkach zakładanych zgodnie z Jednolitym Rzeczowym Wykazem Akt" (§13 ust. 7). Z kolei w $§ 6$ ust. 4 instrukcji UŚ jasno zapisano, że Kancelaria Ogólna prowadzi różnego typu rejestr, w tym także dziennik korespon-

sprawy z równoczesnym ponownym założeniem nowej sprawy może nastąpić dopiero wtedy, gdy sprawa ostatecznie zakończona zaczyna się od nowa lub w przypadku, gdy w wyniku reorganizacji akta spraw niezakończonych przejmuje nowa komórka organizacyjna" (ust. 2).

${ }^{11}$ Również instrukcja dla administracji państwowej i samorządowej w $\S 53$ ust. 3 wyraźnie stwierdza, że „Na każdy rok kalendarzowy zakłada się nowe spisy spraw i nowe teczki”.

${ }^{12}$ Zob. M. Niedźwiedzka, Rejestry kancelaryjne w tradycyjnym i Elektronicznym Zarzadzaniu Dokumentacja (EZD), w: Wspótczesna biurowość w administracji publicznej, Biblioteka Zarządcy Dokumentacji, t. 4, Torun 2013, s.79-89. 
dencyjny. Z kolei na UMCS wprawdzie nie prowadzi się dzienników podawczych (§ 4 ust. 3), ale „odbiór i doręczanie przesyłek odbywa się za pokwitowaniem w odpowiednich rejestrach doręczeń" ( $(6$ ust. 1 pkt. 5) oraz „w razie potrzeby dopuszcza się prowadzenie innych rejestrów wydziałowych” (§ 11 ust. 11).

Reasumując, obowiązująca obecnie instrukcja kancelaryjna KUL w chwili wprowadzenia była niewątpliwie ważnym krokiem ulepszającym system kancelaryjny Uniwersytetu. Dzisiaj jednak odbiega zasadniczo od wzorów charakterystycznych dla tego typu normatywów ${ }^{13}$. Te odmienności widać nie tyle na poziomie samych tytułów poszczególnych rozdziałów, co w szczegółowych zapisach, a czasami w ogólności sformułowań. Jest ona skonstruowana dość chaotycznie, co z pewnością nie sprzyja zrozumieniu i prawidłowemu jej stosowaniu w komórkach KUL. Z pewnością wymaga co najmniej poprawy, bo nie ustrzegła się błędów i nie do końca przemyślanych rozwiązań. Inną kwestią jest nieodłącznie związany z instrukcją jednolity rzeczowy wykaz akt, lecz na omówienie tego normatywu trzeba poświęcić osobny artykuł.

słowa kluczowe: KUL, normatywy kancelaryjno-archiwalne, instrukcja kancelaryjna, system kancelaryjny, obieg pism, kancelaria, registratura

\title{
CHANCERY INSTRUCTIONS OF THE CATHOLIC UNIVERSITY OF LUBLIN, AND THE INSTRUCTIONS OF MARIA CURIE-SKLODOWSKA UNIVERSITY AND THE UNIVERSITY OF SILESIA IN KATOWICE. COMPARISON OF CHANCERY NORMS
}

\begin{abstract}
Summary
Modern chancery of case records is run using the chancery system based on registering particular cases. This system is built on three important chancery-archive norms, which include chancery instructions, a uniform list of records (which is often the annex to chancery instructions) and archival instructions. Without these regulations the smooth functioning of a modern chancery and an institutional archive (records repository) is almost impossible.

Chancery instructions are the ones which play an important role, as their primary function is to establish the rules and procedures for performing chancery tasks in the institution and to standardize the handling of documentation produced by the institution. The proper design of this normative undoubtedly improves the functioning of institutions, optimizes document management processes, contributes to rationalization and im-

${ }^{13}$ Warto zapoznać się chociażby z ustaleniami Haliny Robótki dotyczącymi współczesnych instrukcji kancelaryjnych i treści, które powinny zawierać (Współczesna biurowość. Zagadnienia ogólne, s. 31-46).
\end{abstract}


provement of documents flow within the organization, and streamlines and accelerates the process of performing things. This norm is also needed in higher education, especially at universities. Chancery of the university (understood as a whole organizational unit performing formal and substantive chancery tasks), due to extensive structure of such an institution, is heavily fragmented. It is a legal requirement to have properly constructed chancery instructions (but also other norms) in the case of state universities.

In the case of the Catholic University of Lublin John Paul II there is no legal coercion, but certainly the advantages of using these norms were the basis for its introduction by the Rector of the Catholic University 21 December 2001. The article presents the comparison of the introduced chancery instructions with similar norms in two Polish universities, namely Maria Curie-Skłodowska University, and the University of Silesia. The most important finding of this comparison is recognition of the necessity of issuing new chancery regulations at the Catholic University of Lublin.

Keywords: the Catholic University of Lublin, chancery-archive norms, chancery instructions, the chancery system, documents flow, chancery, registry

Translated by Aneta Kiper 